\title{
TP53-Regulated Inhibitor of Apoptosis 1
}

National Cancer Institute

\section{Source}

National Cancer Institute. TP53-Regulated Inhibitor of Apoptosis 1. NCI Thesaurus. Code C106456.

TP53-regulated inhibitor of apoptosis 1 (76 aa, $9 \mathrm{kDa}$ ) is encoded by the human TRIAP1 gene. This protein is involved in cell survival. 